University of Nebraska - Lincoln

DigitalCommons@University of Nebraska - Lincoln

1996

\title{
Acetochlor in the Hydrologic System in the Midwestern United States, 1994
}

Dana Kolpin

U.S. Geological Survey

Brenda Nations

U.S. Geological Survey

Donald Goolsby

U.S. Geological Survey

E. Michael Thurman

U.S. Geological Survey

Follow this and additional works at: https://digitalcommons.unl.edu/usgsstaffpub

Part of the Earth Sciences Commons

Kolpin, Dana; Nations, Brenda; Goolsby, Donald; and Thurman, E. Michael, "Acetochlor in the Hydrologic System in the Midwestern United States, 1994" (1996). USGS Staff -- Published Research. 73.

https://digitalcommons.unl.edu/usgsstaffpub/73

This Article is brought to you for free and open access by the US Geological Survey at DigitalCommons@University of Nebraska - Lincoln. It has been accepted for inclusion in USGS Staff -- Published Research by an authorized administrator of DigitalCommons@University of Nebraska - Lincoln. 


\section{Acetochlor in the Hydrologic System in the Midwestern United States, 1994}

DANA W. KOLPIN*AND

BRENDA K. NATIONS

U.S. Geological Survey, 400 South Clinton Street, Box 1230, Iowa City, lowa 52244

DONALD A. GOOLSBY

U.S. Geological Survey, Denver Federal Center, Building 25, Lakewood, Colorado 80225

\section{E. MICHAEL THURMAN}

U.S. Geological Survey, 4821 Quail Crest Place,

Lawrence, Kansas 66049

The herbicide acetochlor [2-chloro- $N$-(ethoxymethyl)$\mathrm{N}$-(2-ethyl-6-methylphenyl)acetamide] was given conditional registration in the United States by the U.S. Environmental Protection Agency in March 1994. This registration provided a rare opportunity to investigate the occurrence of a pesticide during its first season of extensive use in the midwestern United States. Water samples collected and analyzed by the U.S. Geological Survey during 1994 doc umented the distribution of acetochlor in the hydrologic system; it was detected in $29 \%$ of the rain samples from four sites in lowa, $17 \%$ of the stream samples from 51 sites across nine states, and $0 \%$ of the groundwater samples from 38 wells across eight states. Acetochlor exhibited concentration increases in rain and streams following its application to corn in the midwestern United States, with $75 \%$ of the rainwater and $35 \%$ of the stream samples having acetochlor detected during this time period. Acetochlor concentrations in rain decreased as the growing season progressed. Based on the limited data collected for this study, it is anticipated that acetochlor concentrations will have a seasonal pattern in rain and streams similar to those of other acetanilide herbicides examined. Possible explanations for the absence of acetochlor in groundwater for this study include the rapid degradation of acetochlor in the soil zone, insufficient time for this first extensive use of acetochlor to have reached the aquifers sampled, and the possible lack of acetochlor use in the recharge areas for the wells examined.

* Author to whom correspondence should be addressed; e-mail address: dwkolpin@usgs.gov; telephone: (319) 358-3614; fax: (319) 358-3606.

\section{Introduction}

The herbicide acetochlor was used extensively for the first time in the United States after its conditional registration by the U.S. Environmental Protection Agency (USEPA) in March 1994 (1). However, acetochlor has had a multiyear history of international use prior to its registration in the United States (2-4). Acetochlor is a preemergentherbicide used to control competing grasses and some broadleaf weeds in corn. An anticipated result of this conditional registration is that the broader spectrum of weed control for acetochlor over alternative corn herbicides will lead to reduced overall herbicide use in the United States (1). Acetochlor is an acetanilide herbicide having chemical structure and properties similar to those of alachlor [2-chloro-2',6'-diethyl- $\mathrm{N}$-(methoxymethyl)acetanilide] and metolachlor [2-chloro- $\mathrm{N}$-(2-ethyl-6-methyl phenyl)- $\mathrm{N}$-(2methoxy-1-methylethyl)acetamide]. Acetochlor has been classified by the USEPA as a B-2 carcinogen (1).

The registration for acetochlor is unique in that registration can be canceled if concentrations consistently exceed $0.10 \mu \mathrm{g} / \mathrm{L}$ in groundwater or $2.0 \mu \mathrm{g} / \mathrm{L}$ as an annual average in surfacewater (1). Theconditions of registration also require an extensive stewardship program on the part of the registrants. This includes restricting the sale of acetochlor in areas that may be vulnerable to contamination, such as areas with sandy soils or shallow water tables.

Even though 1994 was the first year of extensive acetochlor use in the United States, the application of acetochlor was widespread across the midwestern United States (Figure 1). Because of its unique registration requirements, detailed information on the amount of acetochlor used (county-level data) is currently considered confidential (5), and only broad estimates of use could be obtained for this study. Seven percent of the estimated 25 million corn hectares in the midwestern United States received an application of acetochlor during the 1994 growing season (6). Acetochlor was the fifth most heavily used corn herbicide in themidwestern United States during 1994, with about 3.4 million $\mathrm{kg}$ being applied. For comparison, about 9.6 million $\mathrm{kg}$ of alachlor and 17.8 million $\mathrm{kg}$ of metolachlor were used on corn during 1994. An additional 2.7 million $\mathrm{kg}$ of alachlor and 3.2 million $\mathrm{kg}$ of metolachlor were used on soybeans in 1994. Alachlor decreased in use by almost 6 million $\mathrm{kg}$ (about 32\%) between 1993 and 1994 (6), with at least part of this reduction being due to a replacement with acetochlor. The use of atrazine (2-chloro-4-ethylamino-6-isopropylamino-s-triazine), another major corn herbicide, decreased from 22.5 million $\mathrm{kg}$ in 1993to 20.6 million $\mathrm{kg}$ in 1994 . This reduction in alachlor and atrazine use documents that acetochlor is beginning to replace other major corn herbicides, as required by its registration criteria. However, a small increase $(+1.5 \%)$ was noted for metolachlor use between 1993 and 1994.

Because of the unique opportunity to study the distribution of a chemical during its first year of extensive use in the United States, water samples collected as part of three separate ongoing U.S. Geological Survey (USGS) studies of rain, streams, and groundwater in themidwestern United States were analyzed for acetochlor during 1994. The purpose of this paper is to discuss the distribution of acetochlor in the hydrologic system after its first season of 


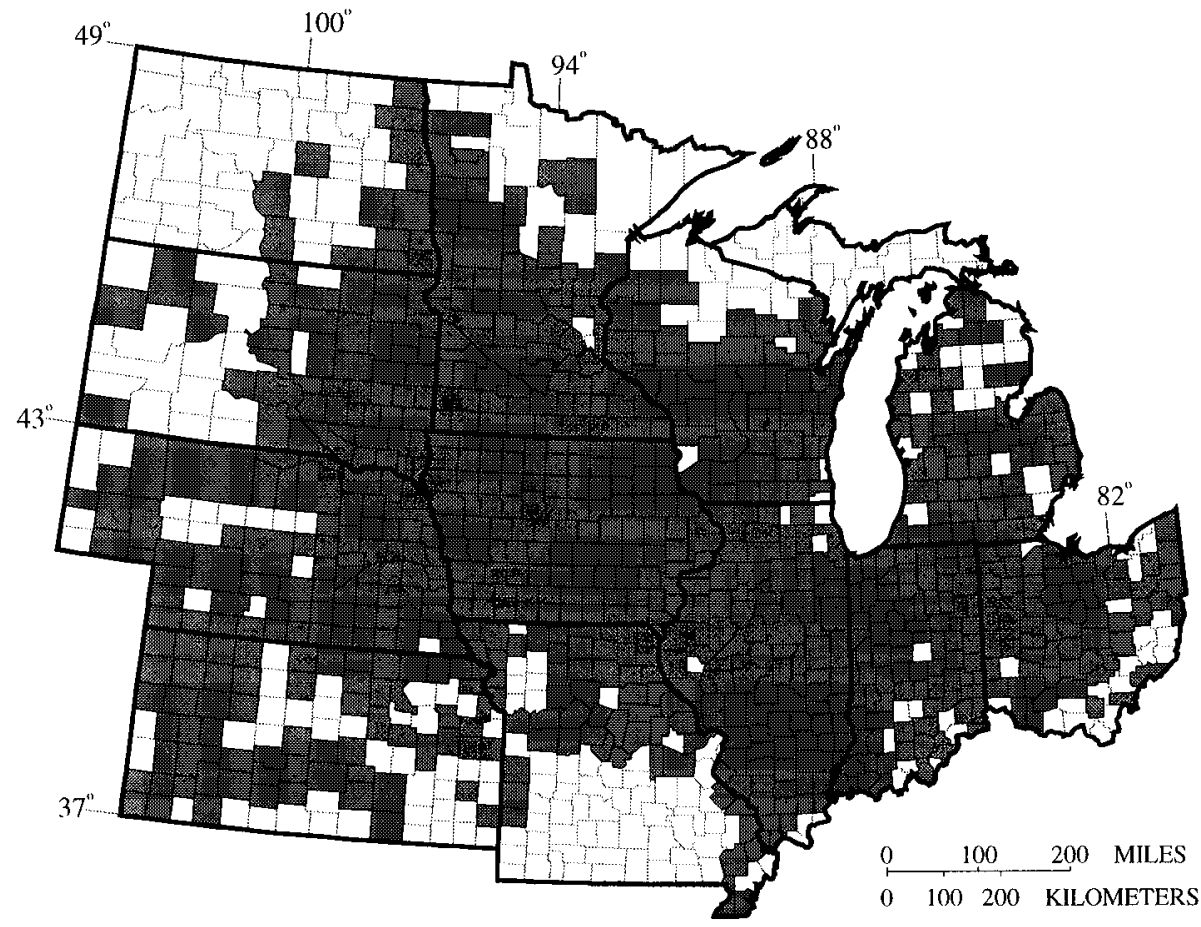

Base from U.S. Geological Survey digital data, 1:2,000,000, 1972

Albers Equal-Area Conic Projection

Standard parallels 3930 and 4330 , Central meridian 9030

FIGURE 1. Location of counties (shaded in map) in the midwestern United States where acetochlor was used during 1994 (5).

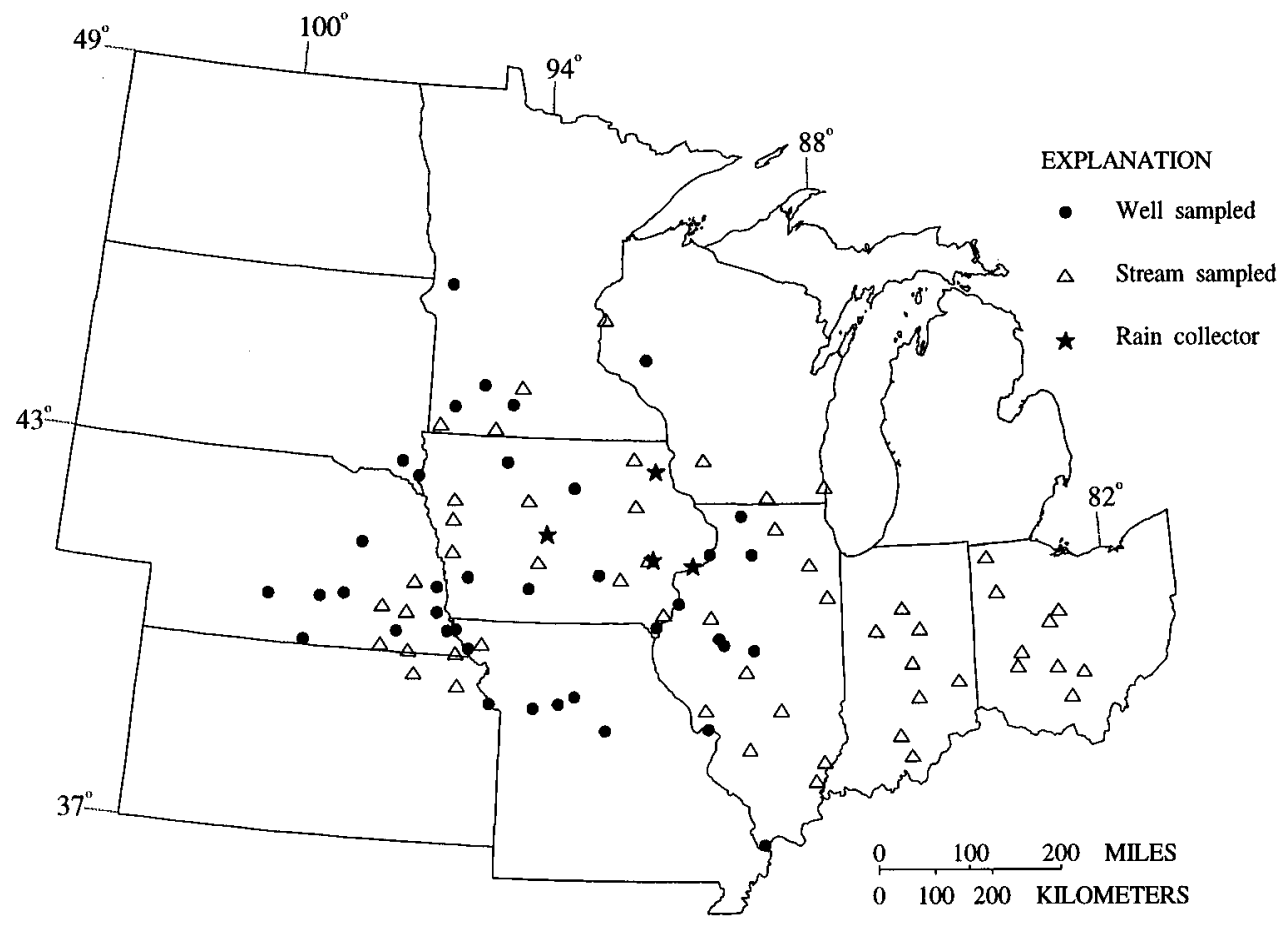

Base from U.S. Geological Survey digital data, 1:2,000,000, 1972

Albers Equal-Area Conic Projection

Standard parallels 3930 and 4330 , Central meridian 9030

FIGURE 2. Location of sites where water samples were collected for acetochlor analysis during 1994.

extensive use on the basis of results of water samples collected from these three studies.

\section{Materials and Methods}

Sampling Program. Water samples were collected from four rainwater sites, 53 streams, and 38 wells in the midwestern United States (Figure 2). Rain samples were collected using automatic wet-dry samplers once a week from late April through August 1994. Three of the rain sites were in proximity $(<150 \mathrm{~m}$ ) to cropland (mainly corn and soybeans), and one site was located in an urban setting (>1600 $\mathrm{m}$ to cropland). These samples were collected as 


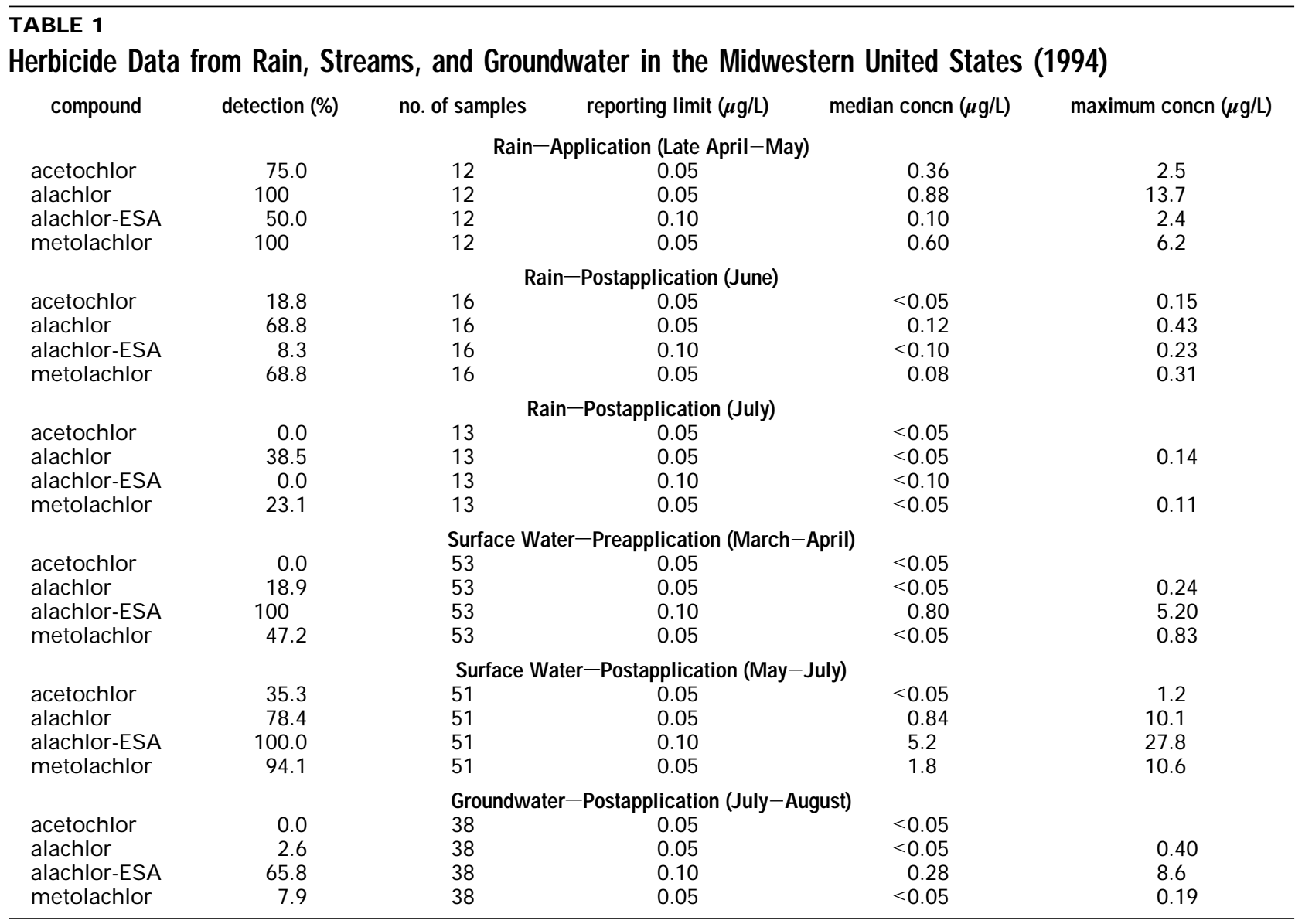

part of a continuing investigation of herbicides in Iowa's rain $(7,8)$. Stream samples werecollected across ninestates during March-April (preapplication) and May-June (postapplication) 1994. Samples were collected with a depthintegrated sampler from three or more verticals and were processed according to a defined protocol (9). The primary objective of thestream sampling was to determine if recent changes in the use of herbicides have affected herbicide concentrations in streams across the midwestern United States.

Groundwater samples were collected from unconsolidated aquifers across eight states during July-August 1994. Unconsolidated aquifers have been documented to bemore susceptible to herbicidecontamination than most bedrock aquifers in the midwestern United States $(10,11)$. Materials and methods used to collect and process the groundwater samples were the same as those used for previous studies usingthis regional monitoring network $(11,12)$. Wells were purged before sampling until $\mathrm{pH}$, water temperature, and specific conductance stabilized. The primary objective of this sampling was to determine the long-term effects of the historic 1993 flooding on groundwater quality and was an extension of a previous study investigating the immediate effects of the 1993 flood (13). These 38 wells are those which had the most severeflooding problems during 1993. However, a Wilcoxon signed-ranked test (14) found the median differences between thesummer 1994samples and the preflood samples (summer 1992 or summer 1991) for these 38 wells were not significantly different from zero ( $p$ $>0.05)$ for the herbicides examined. Thus, these wells should be an adequate representation of unconsolidated aquifers underlying agricultural areas in the Midwest.
Analytical Procedures. All water samples were sent to the USGS Organic Research Laboratory in Lawrence, KS, to determine concentrations of 12 herbicides and two triazine herbicide metabolites. The analytical method included solid-phase extraction of 100-mL water samples on $\mathrm{C}_{18}$ cartridges, followed by gas chromatography/mass spectrometry $(15,16)$. The analytical reporting limit for all compounds was $0.05 \mu \mathrm{g} / \mathrm{L}$. Acetochlor was a new analyte added to the published method $(15,16)$. Recoveries of acetochlor from the $\mathrm{C}_{18}$ cartridges was $95 \% \pm 5 \%$, with a precision of $5 \%$ relativestandard deviation. Acetochlor was determined by selected ion monitoring using the molecular ion (269) and the basic peak ion (223) and a retention time match of $\pm 0.2 \%$ relative to phenanthrene- $d_{10}$. Quantification of acetochlor was based on the area of the basic peak ion (223) relative to the internal standard.

In addition, the alachlor metabolite alachlor ethanesulfonic acid (alachlor-ESA; 2-[(2,6-diethylphenyl)(methoxymethyl)amino]-2-oxoethanesulfonic acid) was extracted and isolated by solid-phase extraction and analyzed by immunoassay (17). The analytical reporting limit for alachlor-ESA was $0.10 \mu \mathrm{g} / \mathrm{L}$.

\section{Results and Discussion}

Acetochlor concentrations were determined for 42 rain, 104 stream, and 38 groundwater samples (Table 1). The results from these samples document the environmental distribution of acetochlor in the hydrologic system after its first year of extensive use in the midwestern United States. Acetochlor was detected in $29 \%$ of the rain, $17 \%$ of the stream, and $0 \%$ of the groundwater samples collected for the three studies. 


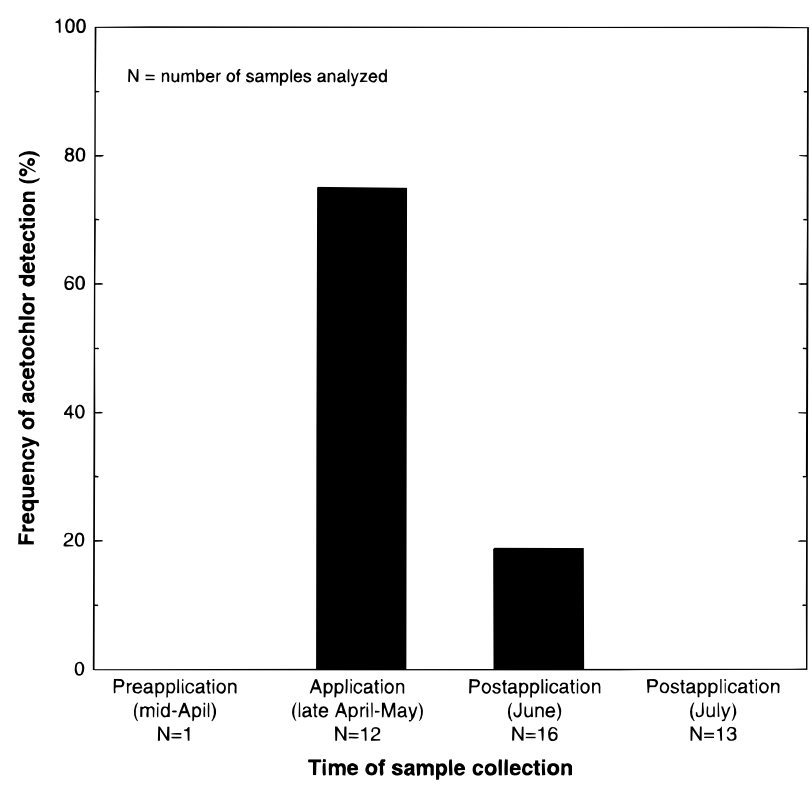

FIGURE 3. Seasonal pattern for the frequency of acetochlor detection in rainfall from four sampling sites in low a during 1994.

Rain. Acetochlor exhibited a seasonal pattern in the rain samples from lowa (Figure 3). Acetochlor concentrations were found to be significantly higher during the late April-Maytime period than those found during either June or July ( $p<0.001$; Mann-Whitney test (14)). Other research has also documented the presence of acetochlor in rain (18). The results of this study suggests that the higher acetochlor concentrations in rain during lateApril and May were the result of the recent chemical applications associated with corn planting in the midwestern United States during 1994. Acetochlor follows a seasonal pattern similar to that of the other acetanilide herbicides analyzed at all of therain-collection sites (Figure4). Even though extensive seasonal data were available only for the rain-collection site in northeastern lowa, the data for the remaining raincollection sites, where present, match those from this site. Previous research has shown that alachlor exhibits astrong seasonal and spatial pattern in rain, with concentrations being the highest and detections most frequent in the midwestern United States during the period of mid-Aprilmid-July $(19,20)$. In areas outside the midwestern United States, alachlor concentrations were low and detections infrequent, with concentrations and frequencies of detection decreasing away from the midwestern United States. This suggests that the source of the alachlor concentrations in rain was the recent applications associated with crop planting in the midwestern United States $(19,20)$. Thus, since the seasonal patterns were similar between alachlor and acetochlor, it follows that themajor source of acetochlor in rain for thisstudy must al so be derived from applications to corn fields in the midwestern United States and not from applications in other parts of the world. The differences in frequencies of detection and maximum concentrations between acetochlor and the other acetanilide herbicides (Table 1, Figure 4) may, in part, bea function of differences in the amounts of chemical used during 1994.

Volatilization may be a significant process in the atmospheric transport of acetochlor, as has been determined for alachlor. Research by Glotfelty et al. (21) documented that $19 \%$ of the alachlor applied to a fallow soil in eastern Maryland was lost to the atmosphere within 21 days as the result of volatilization. A simple empirical
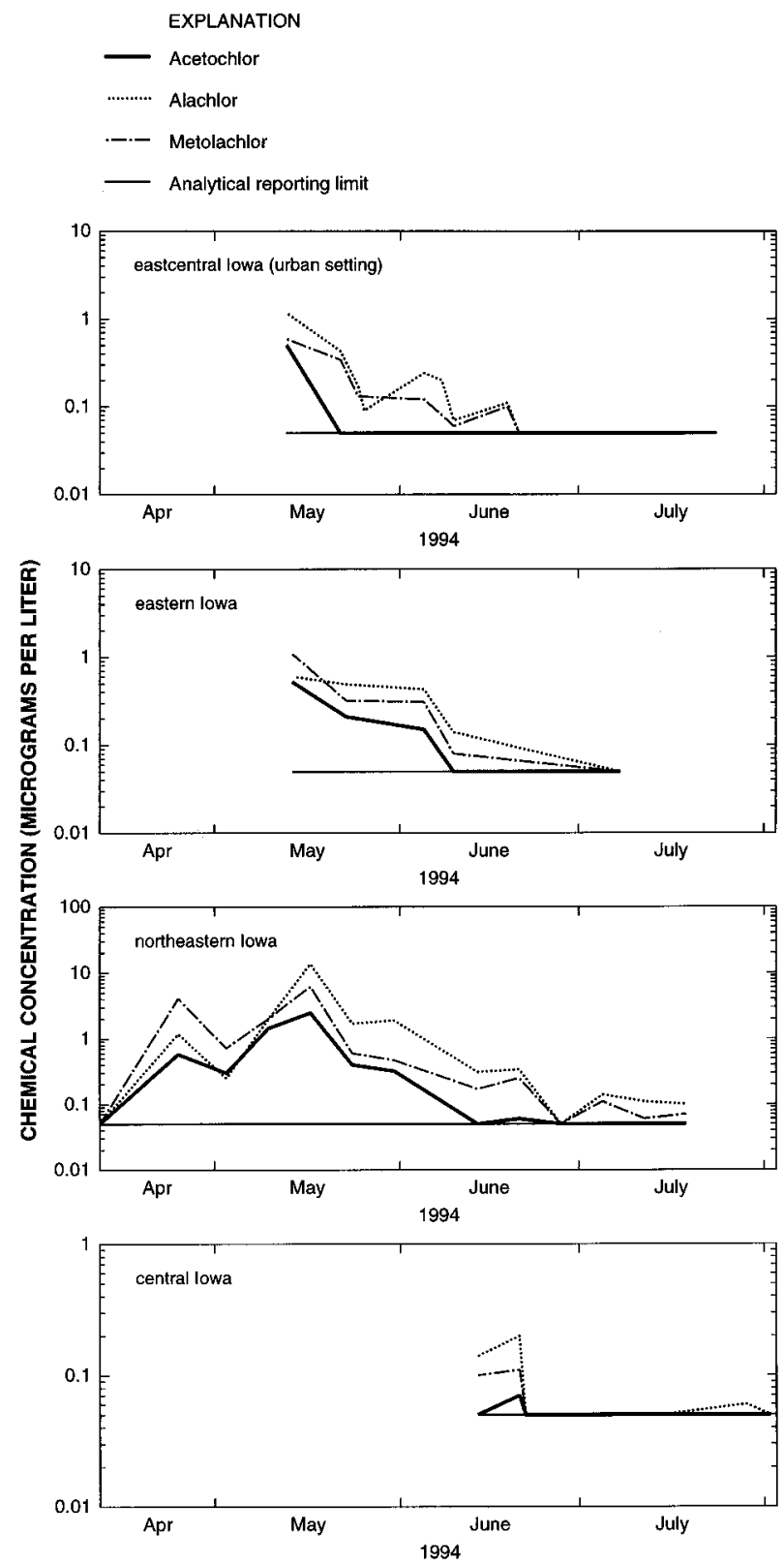

FIGURE 4. Concentrations of acetanilide herbicides in rainfall during 1994 from four sampling sites in lowa.

equation (21) was used to compare the relative volatility of alachlor to acetochlor. A volatilization rate constant, $\mathrm{K}_{\mathrm{v}}$, is given by

$$
\mathrm{K}_{\mathrm{v}}=\mathrm{Q}\left(\mathrm{P} / \mathrm{K}_{\mathrm{oc}} \mathrm{S}\right)
$$

where $\mathrm{P}$ is the vapor pressure $(\mathrm{mmHg}), \mathrm{K}_{\mathrm{oc}}$ is the soil adsorption coefficient $\left(\mu \mathrm{g} \mathrm{g}^{-1}\left(\mu \mathrm{g} \mathrm{mL}^{-1}\right)^{-1}\right.$, organic carbon basis), $\mathrm{S}$ is the solubility ( $\mathrm{mg} / \mathrm{L})$, and $\mathrm{Q}$ is an empirically determined coefficient equal to $4.4 \times 10^{7}(21)$. Alachlor was found to have a $K_{v}=24 \times 10^{-3} /$ day, where $P=2.2 \times$ $10^{-5}(22), K_{\text {oc }}=170$ (23), and $\mathrm{S}=242$ (22). Acetochlor was found to have a $K_{v}=35 \times 10^{-3} /$ day, where $P=4.4 \times 10^{-5}$ (21), $K_{\text {oc }}=239$ (22, median value for data from five soils), and $\mathrm{S}=233$ (22). Thus, although $\mathrm{K}_{\mathrm{v}}$ does not take into account other factors that also influence chemical volatilization, such as soil organic matter content, antecedent soil moistureconditions, or chemical concentrations, it does show that acetochlor likely has potential for volatilization to theatmospheresimilar to that of alachlor. If theamount 


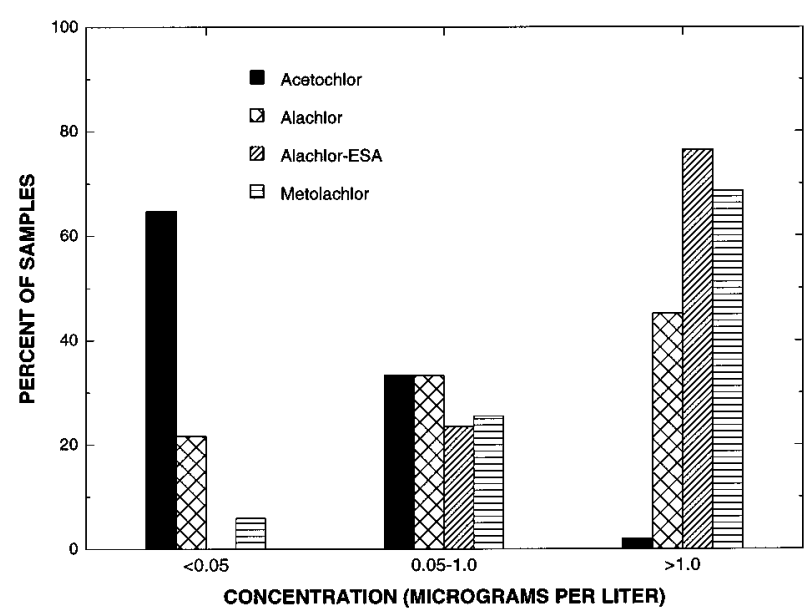

FIGURE 5. Concentrations of selected herbicide compounds in streams across the midwestern United States (May-J une, 1994).

of acetochlor used increases as required as a part of the registration criteria (1), a corresponding increase in the frequencies of detection and concentrations of acetochlor in rainfall should be expected.

Surface Water. Acetochlor was detected in about onethird of the 51 streams sampled following the spring chemical applications associated with corn planting. Based on the limited data collected for this study, it is anticipated that acetochlor concentrations will have a seasonal pattern in streams across the midwestern United States similar to those of the other acetanilide herbicides analyzed in that an increase in concentration will occur between the spring and summer samples (Table 1). This "spring flush" phenomenon of pesticides into streams across the midwestern United States has been documented in the literature $(24,25)$. The much lower concentrations for acetochlor (Table 1, Figure 5) likely reflect the substantially lower amounts of acetochlor used compared to other herbicides examined (6). Previous research has shown that chemical use is an important factor in the transport of pesticides to streams across the midwestern United States (24-27). As expected, no acetochlor concentrations were found in any streams sampled during spring 1994, prior to the first extensive use of this chemical. Streams that contained acetochlor were distributed across the entire midwestern United States (Figure6), with no spatial patternsin detection being apparent. No statistically significant ( $p<0.05$; Spearman's $\rho$ (14)) correlation was determined between acetochlor concentrations in streams and the various land useand hydrogeologic factors of the basinssampled. These basinal factors examined included \% corn, \% rowcrops, \% harvested cropland, \% irrigated cropland, drainage area, average soil permeability, average soil hydrologic group number, and average precipitation (28). The factors having the largest correlation coefficients were the \% of basin in rowcrops (0.2287, $p=0.1065$; Spearman's $\rho$ ) and \% of basin in harvested cropland $(0.2278, p=0.1078$; Spearman's $\rho$ ). Because the detailed acetochlor use data are currently considered confidential, a more in-depth examination was not possible at this time.

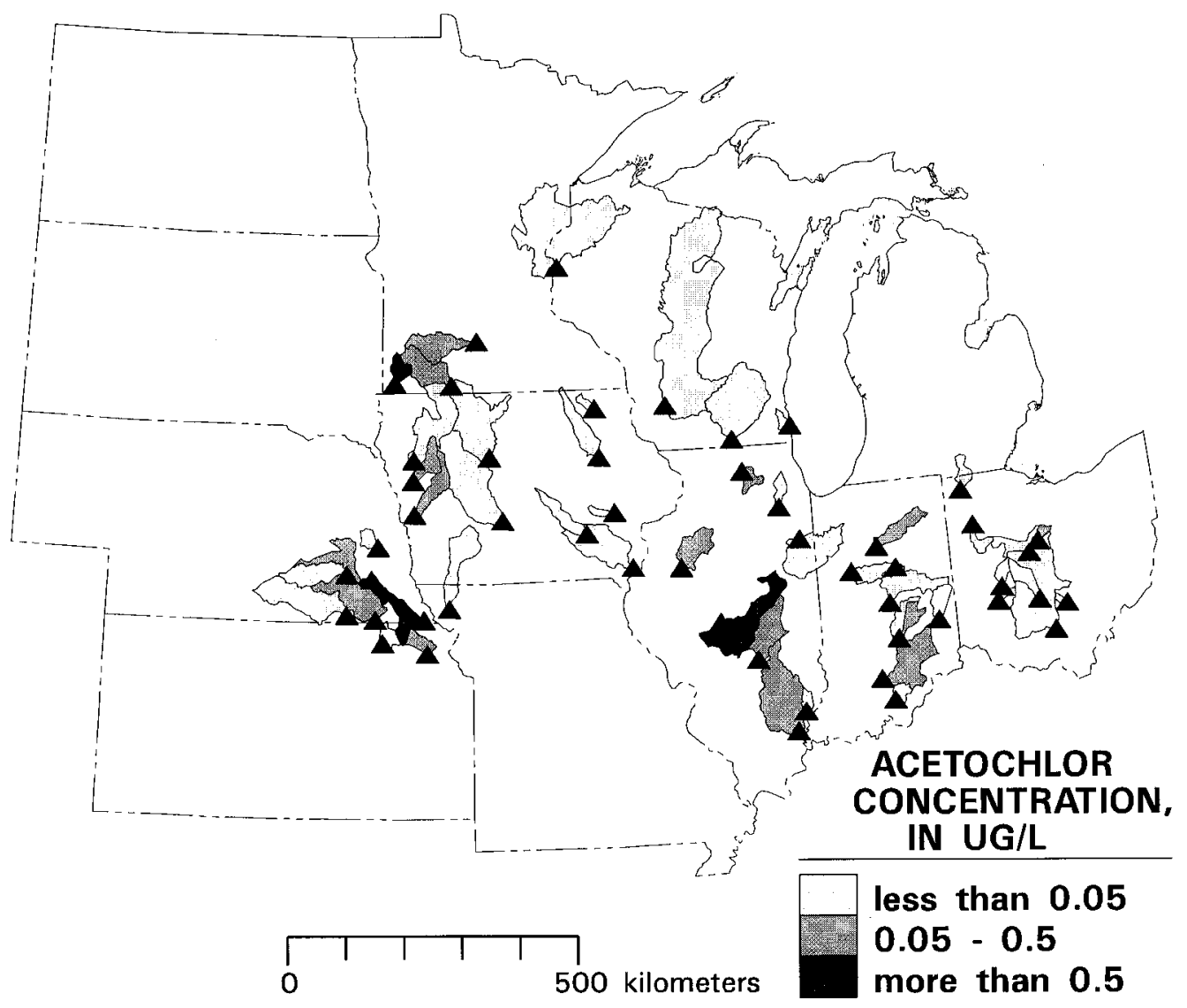

- Sampling site

FIGURE 6. Spatial distribution of acetochlor concentrations in streams across the midw estern United States for the May-J une (postapplication) sampling period, 1994. 
Groundwater. No acetochlor was detected above analytical reporting limits for any of the 38 wells sampled across eight midwestern states. There are several possible explanations for the absence of acetochlor in groundwater for this study. First, acetochlor may degrade rapidly in the soil zone. Research has shown that some herbicides may be substantially degraded in soils. A transport study of herbicides in an unconsolidated aquifer in Nebraska found that as much as $40 \%$ of the parent alachlor was removed from solution during a 2-month experiment (29). Alachlor has been documented to degrade to a more mobile and persistent metabolite, alachlor-ESA (30-34). Alachlor-ESA was detected $>25$ times more often than its parent compound for this study (Table 1). Acetochlor also has a sulfonic acid metabolite, acetochlor sulfonic acid [ethoxymethyl(6-ethyl-o-tolyl)carbamoylmethanesulfonic acid], similar to alachlor-ESA (1). Given the similar estimated halflives between alachlor (15 days) (22) and acetochlor (14 days) (22), we suggest that acetochlor sulfonic acid will be detected in groundwater in acetochlor use areas when an analytical method becomes available.

A second possible explanation for the absence of acetochlor in groundwater is that insufficient time may have been available for this first extensive application of acetochlor to havereached theaquifers sampled. Research has shown that alachlor has only slight retardation when compared to a conservative tracer (29). A herbicide transport study found the alachlor required over 30 days to travel $5.5 \mathrm{~m}$ from the point of injection at a depth of 3.3 $\mathrm{m}$ (29). Thus, thetimeavailable(roughly 60-120 daysfrom the initial acetochlor applications) and the distances involved (median well depth of $13.6 \mathrm{~m}$ plus unknown horizontal path lengths) suggest that acetochlor transport to many of the wells sampled may have been unlikely.

A third possibility for the absence of acetochlor in groundwater may be the lack of acetochlor use in the rechargeareasfor thesewells. Currently, the most detailed acetochlor use data were considered confidential and thus were unavailable for this study. However, given the widespread nature of acetochlor applications across the midwest (Figure 1), it is likely that acetochlor was used in the recharge areas of at least a subset of the wells sampled during 1994.

\section{Acknowledgments}

The authors thank the U.S. Environmental Protection Agency, Office of Ground Water \& Drinking Water, for funding thesample collection and analysis of groundwater; the U.S. Geological Survey, Toxics Substances Hydrology Program, for funding the sample collection and analysis of surface water; and the U.S. Geological Survey, National Water-Quality Assessment Program, for its contribution to the funding of the data analysis. The authors also thank the Iowa Department of Natural Resources, Geological Survey Bureau, and Department of Agricultural Engineering, lowa State University, for providing assistance in the collection of rain samples.

\section{Literature Cited}

(1) U.S. Environmental Protection Agency. Prevention, Pesticides and Toxic Substances. Questions and Answers, Conditional Registration of Acetochlor; U.S. EPA: Washington, DC, Mar 11, 1994; $18 \mathrm{pp}$.

(2) Cohen, R. Crop Protect. 1992, 11, 181-185.

(3) Jablonkai, I.; Hatzios, K. K. Pestic. Biochem. Physiol. 1991, 41, $221-231$.
(4) Van Rensburg, E.; Van Dyk, L. P.; De Swardt, G. H. South Afr. J. Plant Soil 1990, 7, 113-116.

(5) Behl, E. U.S. Environmental Protection Agency, written communication, 1995.

(6) U.S. Department of Agriculture. Agricultural Chemical Usage: 1994Field CropsSummary; USDA, National Agricultural Statistics Service, Economic Research Service, Ag Ch 1 (95); Agricultural Statistical Board: Washington, DC, March 1995; 106 pp.

(7) Nations, B. K.; Hallberg, G. R. J. Environ. Qual. 1992, 21, 486492.

(8) Nations, B. K.; Hallberg, G. R.; Libra, R. D.; Kanwar, R. S.; Alexander, E. C., Jr. In Agricultural Research to Protect Water Quality-Proceedings of the Conference, Minneapolis, MN, Feb 21-24, 1993; Soil and Water Conservation Society: Ankeny, IA 1993; pp 142-145.

(9) Goolsby, D. A.; Boyer, L. L.; Battaglin, W. A. Open-FileRep. U.S. Geol. Surv. 1994, No. 94-347.

(10) Burkart, M. R.; Kolpin, D. W. J. Environ. Qual. 1993, 22, 646656.

(11) Kolpin, D. W.; Burkart, M. R.; Thurman, E. M. Water-Supply Paper U.S. Geol. Surv. 1994, No. 2413.

(12) Kolpin, D. W.; Burkart, M. R. Open-File Rep. U.S. Geol. Surv. 1991, No. 91-59.

(13) Kolpin, D. W.; Thurman, E. M. Circular U.S. Geol. Surv. 1995, No. 1120-G.

(14) Helsel, D. R.; Hirsch, R. M. Statistical methodsin water resources; Elsevier: New York, 1992.

(15) Thurman, E. M.; Meyer, M.; Pomes, M.; Perry, C. A.; Schwab, P. Anal. Chem. 1990, 62, 2043-2048.

(16) Meyer, M. T.; Mills, M. S.; Thurman, E. M. J. Chromatogr. 1993, 629, 55-59.

(17) Aga, D. S.; Thurman, E. M.; Pomes, M. L. Anal. Chem. 1994, 66, 1495-1499.

(18) Capel, P. D.; Ma, L.; Schroyer, B. R.; Larson, S. J.; Gilchrist, T. A. Environ. Sci. Technol. 1995, 29, 1702-1705.

(19) Richards, R. P.; Kramer, J. W.; Baker, D. B.; Krieger, K. A. Nature 1987, 327, 129-131.

(20) Goolsby, D. A.; Thurman, E. M.; Pomes, M. L.; Meyer, M.; Battaglin, W. A. Open-File Rep. U.S. Geol. Surv. 1993, No. 93418, 75-89.

(21) Glotfelty, D. E.; Leech, M. M.; Jersey, J.; Taylor, A. W. J. Agric. Food Chem. 1989, 37, 546-551.

(22) U.S. Environmental Protection Agency. Environmental Fate Oneliner Data Base; U.S. EPA: Washington, DC, 1995; Version 3.04.

(23) Becker, R. L.; Hergfel, D.; Ostlie, K. R.; Stamm-Katovich, E. J. Pesticides-Surface runoff, leaching, and exposure concerns; University of Minnesota Extension Service publication AG-BU3911; 1989; 32 pp.

(24) Thurman, E. M.; Goolsby, D. A.; Meyer, M.T.; Mills, M. S.; Pomes, M. L.; Kolpin, D. W. Environ. Sci. Technol. 1992, 26, 2440-2447.

(25) Schottler, S. P.; Eisenreich, S. J.; Capel, P. D. Environ. Sci. Technol. 1994, 28, 1079-1089.

(26) Goolsby, D. A.; Battaglin, W. A. In Agrochemical Environmental Fate, State of the Art; Leng, M. L., Leovey, E. M. K., Zubkoff, P. L., Eds.; Lewis Publishers: Chelsea, MI, 1995; pp 159-173.

(27) Larson, S. J.; Capel, P. D.; Goolsby, D. A.; Zaugg, S. D.; Sandstrom, M. W. Chemosphere 1995, 31, 3305-3321.

(28) Battaglin, W. A. U.S. Geological Survey, written communication, 1995.

(29) Widmer, S. K.; Spalding, R. F. J. Environ. Qual. 1995, 24, 445453.

(30) Macomber, C.; Bushway, R.; Perkins, L.; Baker, D.; Fan, T. S.; Fergurson, B. S. J. Agric. Food Chem. 1992, 40, 1450-1452.

(31) Baker, D. B.; Bushway, R. J.; Adams, S. A.; Macomber, C. Environ. Sci. Technol. 1993, 27, 562-564.

(32) Kolpin, D. W.; Goolsby, D. A. Int. Assoc. Hydrol. Sci. 1995, 225, 13-20.

(33) Potter, T. L.; Carpenter, T. L. Environ. Sci. Technol. 1995, 29, 1557-1563.

(34) Kolpin, D. W.; Goolsby, D. A.; Thurman, E. M. J. Environ. Qual. 1995, 24, 1125-1132.

Received for review May 12, 1995. Revised manuscript re ceived January 5, 1996. Accepted January 18, 1996. ${ }^{\circledR}$

\section{ES9503241}

${ }^{\otimes}$ Abstract published in Advance ACS Abstracts, March 15, 1996. 